Grzegorz First

Krakow

\title{
POLYCEPHALY - SOME REMARKS ON THE MULTI-HEADED NATURE OF LATE EGYPTIAN POLYMORPHIC DEITIES
}

\begin{abstract}
One of the most intriguing motifs of Egyptian religious iconography is the representation of 'pantheos', a composite deity with additional animal heads and other animal attributes, as well as magical and religious symbols. This group is commonly described in Egyptology as pantheistic, although the new definition of 'polymorphic' has recently been proposed. This term does not lean towards any particular area of interpretation, but simply refers to a single visual aspect of the motif.

The group of Late Egyptian, Ptolemaic and Roman objects with this type of representation consists of statuettes, magical stelae, amulets, illustrations on papyriand gems. The main feature of polymorphic deities is their additional animal elements, which are attached to the basic corpus. These elements are mostly heads, wings and other parts of the animal's body, although polymorphic depictions also sometimes contain ithyphallic or androgynous elements. The most important element of polymorphic iconography and its interpretation is the multi-headed nature of the images. This suggests both that complicated thought processes created the composition of the depictions and that they had a close relationship to magic and religion. A polymorphic representation was not a simple visualisation of just one religious idea or god, but was testament to the diverse thinking behind popular and official beliefs in ancient Egypt in the second half of the 1st millennium BC and in later times. The debate on polymorphism centres either on the possible search for a personal, universal god with a solar, hidden aspect
\end{abstract}


or focuses on the magical, practical dimension, which provided protection for the people from evil powers and dangers.

Keywords: Religion; magic; Late Egyptian religious iconography

\section{Introduction - the pantheistic and the polymorphic}

One of the most characteristic features of Egyptian religious iconography is the variety and mixture of symbolic concepts with sophisticated meanings that are visible in magical and personal cult objects. A particularly interesting category consists of 'pantheistic deities', which are depicted with additional animal heads, as well as multiple other animal and magical attributes (Kákosy 1977, 145-148; Hornung 2000, 1-20; Kákosy 2000, 45-49; Kaper 2003, 91-99). These depictions have been known since the beginnings of Egyptology, yet an in-depth study devoted to their context and function has not yet been conducted.

The terms 'pantheistic deities' and 'pantheos', which are still in common usage in Egyptology, are sometimes criticised for providing a rather uncertain interpretation of this type of depiction (Leitz 1994, 244; Kaper 2003, 85-104; Koenig 2011, 252-253). The adoption of the term 'paniconic' has also been suggested to signify a composite depiction focused on one god, as opposed to pantheistic images, which focus on a multitude of gods (Meeks 1986, 184; Zivie-Coche 2004, 20). In 2006, J. F. Quack (2006a, 175-190) proposed the definition of 'polymorphic deities', a term that does not limit itself to a singular interpretation and refers only to the visual nature of the motif. Naturally, this term can be regarded as questionable; 'polymorphic' does not possess much of a religious connotation, being more connected to the biological and physical realms. However, the term is already used in reference to certain religious systems, such as Hinduism. Within the context of Egyptian religious iconographic terminology, it is also necessary to mention the expression 'polymorphic monotheism', which refers to the 21 st Dynasty and to the concept of multiple representations, images and names of one singular deity. This god is 'in everything and everything is in God' (Niwiński 1989, 89-106; Niwiński 2000, 28). The term is also used in the context of Gnostic depictions of God in various forms known from early Christianity. This is an area that certainly merits further study (Stroumsa 1981, 412-434; Junod 1982, 38-46; Koenig 1998, 661-664).

The term 'pantheistic deity' traditionally refers to a representation which includes a conglomeration of human and animal elements, such as the heads of various animal species with other animal body parts such as wings, tails, 
genitalia and legs (Fig. 1). It has been stated that at least four additional heads or other animal body parts are required for an image to warrant this description (Kaper 2003, 97; Lieven 2005, 32; Quack 2006a ,175; Cosens 2007, 181-184). Pantheos representations also include numerous embedded magical symbols, such as a snake eating its own tail (ouroboros), knives and the royal insignia held by the deity depicted. Certain elements of the body are often multiplied, most often the eyes, wings or arms. This kind of representation is shown en face, which is rare in Egyptian iconography and therefore emphasises its unique character (Romano 1980, 39-56; Volokhine 1994, 92-95; Volokhine 2000, 69-83). The overload and combination of various attributes is another characteristic feature that gives the examples their 'hybrid' nature, in which human elements are replaced by mixed animal and magical elements, which are sometimes androgynous (Fischer 1987, 13-26; Hornung 2000, 17-20; Zivie-Coche 2004, 15, 26-28). All of the features described above do not, however, present an exhaustive description of pantheistic images. This is due to the hugely varied nature of pantheistic iconography, the lack of a 'canonical form' and the difference in deity depictions, which depends on the type of object upon which the representation is found. In addition, many images described in older literature as pantheistic can now be regarded as a form of the sun god or other deities. They may also have royal origins and could have provided protection for the king (Quack 2006b, 53-64).

There is still no commonly accepted attitude for dealing with the issue of polymorphic/pantheistic images, but it is generally agreed that their meaning and interpretation are both interesting and ambiguous (First 2011, 53-64). The currently very topical subject of ancient Egyptian 'visual archaeology' is worth much consideration when dealing with iconography, symbolic studies and semantic research.

Fig. 1. Polymorphic deity on the healing statue of Pa-Maj (Napoli, Museo Archeologico Nazionale, inv. no. 1065). Reproduced from Myśliwiec 1978, Abb 92

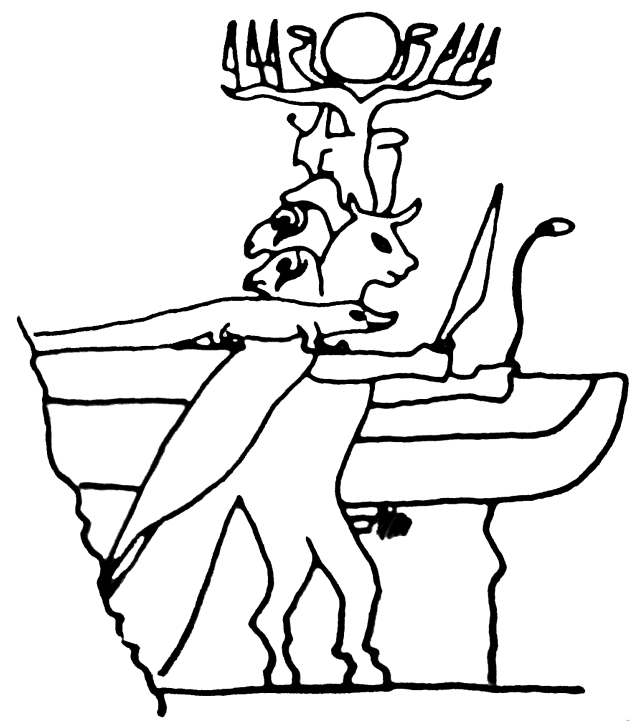




\section{Multi-headed as a polymorphic}

The main feature of a polymorphic deity is the addition of animal elements, which are attached to the basic corpus. These elements are mostly heads, wings and other parts of the animal body. Polymorphic depictions are also known for their ithyphallic and sometimes androgynous elements, which do not have any sexual connotations, but rather symbolise aggression and power. The following elements can also be seen as features of polymorphic iconography: a mixture of symbolic and magical elements of different origins, the multiplication of certain elements and amalgams of animal components that nevertheless retain their separate nature.

A significant distinction should be made between deities with the heads of different animal types and deities with the heads (most often four) of one type of animal, as the latter is a clear manifestation of the Sun or Great God (Myśliwiec 1978, 51-62). One example of this is the four-headed god on the centre of hypocephali (Gee 2001, 325-334). It is also worth mentioning the 'Lord of Many Faces', the 'Lord of Many Forms' and other forms of the Great God from early 21st Dynasty iconographical sources, which may be interpreted as later versions of figures from the Litany of Ra (Piankoff 1964, 10-12, 19; Niwiński 2000, 33-35). Additionally, O. Kaper $(2003,87)$ has pointed out that the presence of a theriomorphic attribute does not necessarily mean a depiction is pantheistic. The core element here is 'pluriformity', which can be collated with 'polymorphism'.

\section{Multi-headedness in iconography}

As mentioned previously, the main feature of polymorphic representations is that of additional animal heads, which are usually placed alongside the deity's head. The range of additional heads used was wide, but most often were the heads of animals worshipped as incarnations of Egyptian deities related to the cult of the Sun. The number of additional heads was not incidental. There had to be at least four heads and some possessed as many as seven or nine heads. Representations with an even higher number of heads are rare, although a few with twelve heads do exist, such as a healing statue of Djedhor (Fig. 2; Jelínková-Reymond 1956, 22, 37; Hornung 2000, 46-47). It should be noted here that the kind of animal used was not normally repeated, meaning the animal heads were generally of different animal species. This feature strongly distinguishes polymorphic representations from the four-headed (normally of the ram) images of the Sun God that 
Fig. 2. Polymorphic deity on the healing statue of Djedhor, 4th century BC (Egyptian Museum in Cairo, inv. no. 46341). Reproduced from Hornung 2000, 46-47.

we know from hypocephali and other sources. The animal heads used in polymorphic representations are those of the ram, the bull, the lion, the dog (jackal), the falcon, the baboon, the cat and the crocodile. Symmetry was always maintained, meaning that the heads were placed evenly on both sides of a central head. Sometimes, the depictions are comple-

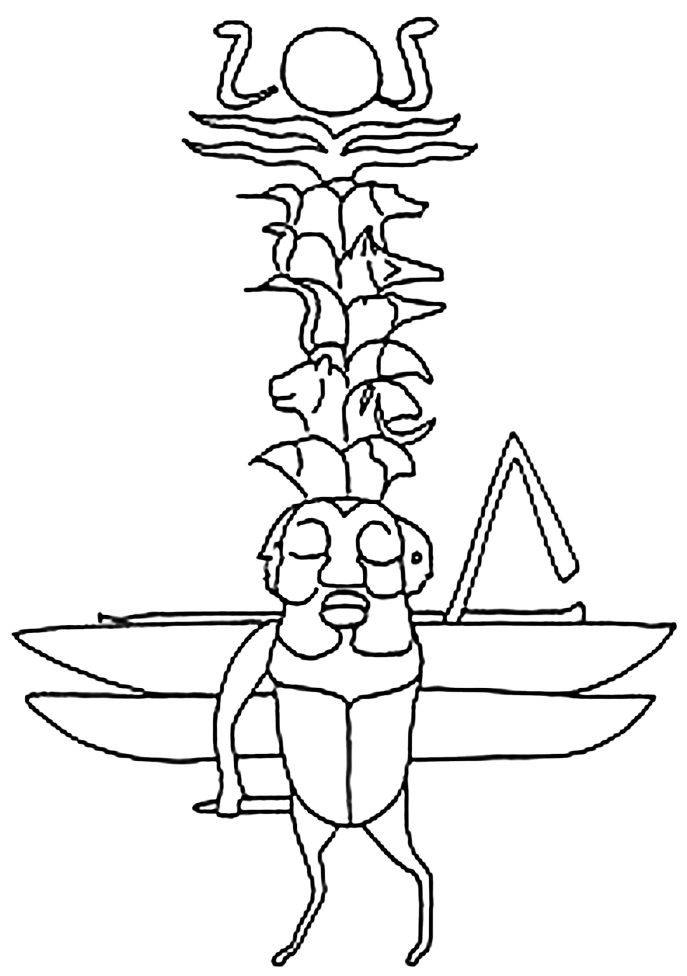
mented by a crown. In such cases, the heads grow out of the crown, as in one of the best known examples on Metternich's stela, in which the crown consists of a high kalathos, crowned with a pair of ram horns, four pairs of knives and a seated figure with hands lifted up/the infinity symbol (Fig. 3; Pleyte 1881, 128-132; Sternberg el-Hotabi 1987, 25-69; Sternberg el-Hotabi 1999, Teil 1, Abb. 113; Kákosy 2002, 284, fig. 2). In other representations, the crown consists of solar discs, ostrich feathers and uraeuses, instead of ram horns and knives. In these cases, the component elements are sometimes multiplied.

\section{The central face}

The starting point for analysing the meaning of polymorphic deities with a central head must be to note the domination of the head of Bes. On the one hand, it must be acknowledged that the head of Bes does appear alongside other features of the deity (visible in other parts of the polymorphic figure) and that this often dominates the whole depiction, resulting in the mistaken interpretation of the figure as Bes (Kaper 2003, 102). However, as was 


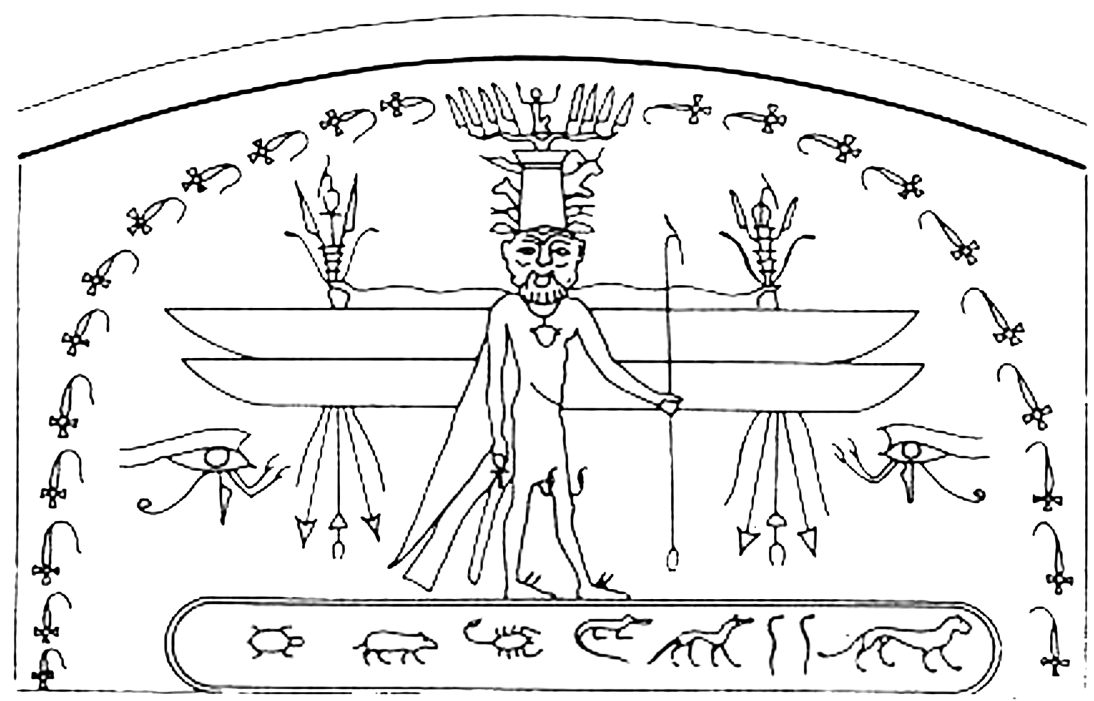

Fig. 3. 'Bes Pantheos' on the stela of Metternich - register IX, 30th Dynasty (Metropolitan Museum of Art, New York, inv. no. 50.85). Reproduced from Sternberg el-Hotabi 1999, Teil 1, Abb 113.

noted as early as 1966 by L. Kákosy, Bes should be treated in this instance as a 'transmitter/vehicle' - a tool for depicting the idea and not the features of Bes himself (Kákosy 1966, 185-196; Derchain 1969, 31-34). The face of Bes has a universal and capacious nature and is not linked to any other 'official' deity as a symbol or attribute (Amun with face of Bes: Michailidis 1968, fig. 31, pl. III). The composed face of Bes (as well as his other features) highlights the universal nature of the polymorphic figure. In cases when a depiction of another deity in either human or animal form is present, the polymorphic figure is dominated by that particular deity. Bes did not pose the danger of 'domination' and, as a result, there is no dominating head when the face of Bes is not employed. For the record, it should be noted that some depictions do exist that bore other faces, but their modest number makes them far from noteworthy at present.

The lack of a deity's head is rare, but it is not unusual in complex religious iconography (Meeks 1991, 5-15; Hornung 2000, 1-20). However, in the case of polymorphic depictions, what we can see is not a missing head, but rather multiple heads functioning together as one central head. This visual content 'solution' is common in iconography and is often used in depictions of the solar deity in human form (sometimes mummified) 
sitting with four ram heads and a crown. Despite its common description as pantheistic and its visual similarity, this image is not polymorphic in itself, as it only depicts a multiplied aspect of the solar deity. It can also be found on various different objects. In most cases, the figure has the head of just one animal species, which is usually the ram. An example of such a figure, which is incredibly interesting due to its rare usage of three-dimensional iconography, is a statue of a ram with four heads made of lapis lazuli that comes from Kom el-Ahmar (Wainwright 1925, 145-147). In most cases, this deity occurs on the vignettes of papyrus, healing statues and sarcophagi and is also a distinguishing feature and the central motif of hypocephali. Both this item itself and the scenes shown on it are closely related to chapter 162 of the Book of the Dead, which discusses flames over the head of the deceased and, despite the image's solar nature, is evidence of a close relationship with the Osiriac circle (Yoyotte 1977, 194-202; Gee 2001, 325-334; Vallée 2009, 137-144). In most cases, however, the four ram head deity scene symbolises the moment of the sun's birth on the horizon (Haslauer 2001, 173-184; Miatello 2008, 277-287; Czerkwiński 2011, 19-25). It should be added that this is a rebirth (or even multiple rebirth) that is accompanied by the screaming of baboons. At this particular moment (the end of the night and the beginning of the day), the deity reveals his non-unified nature. According to one of the Ptolemaic texts from Mendes, the deity with four ram heads is a living emanation of $\mathrm{Ra}$, Shu, Geb and Osiris and appears 'on the horizon with four heads lighting up the sky and the earth, coming as the Nile to make the soil alive and to provide air to humanity' (Naville 1894, 21). The head of the deity represents fire, earth, water and air and all four elements, depicted by ram heads, are equal to one another.

The interpretation of the polymorphic figure with the central head of Bes and an additional twelve animal heads on the healing statue of Djedhor of Cairo is of particular interest. The head of Bes is here accompanied by two additional heads with a schematically drafted profile. It seems that the depiction could be an attempt at a three-dimensional representation of the deity with the four heads directed in the four different directions of the world, known as the 'quadrifrons' or 'quadricephalous' (Kákosy 2000, 47). This kind of representation is primarily known from the iconography of Hathor and Amun-Ra, but it should also be noted that there are Demotic names in which the epithet of the four faces of Min or Montu occurs. These can be identified as epithets of the cosmic and fertile aspects of Amun-Min. According to J. Quaegebeur (1991, 253-268), Theban theology enriched the four-headed Min or Montu with the aspects 
of a deity responsible for creation in the Late period. The presence of Bes quadrifrons would thus be an attempt to depict the cosmic and creative aspect of the god, further enhanced by the unique and therefore significant amount of additional animal heads emerging from his quadrupled head.

In summary, it is worth emphasising the fact that the domination of the face of Bes (en face) is related on one level to his universal and capacious significance and on the other to his undoubtedly solar nature. Naturally, the front depiction performs an apotropaic function, as the directing of eyes towards a person is supposed to provide protection, care and permanent contact (compare with the Greek Gorgon: Hagen 2007, 1-65). The face of Bes may thus be included into the large category of grim, evil face depictions that aim to cripple the enemy and transmit a signal of an aggressive nature common across many cultures (Ogden 1985-1986, 32 , footnotes 17 and 18). Bes on his own is supposed to scare enemies away and this useful and traditional function should not be forgotten. The polymorphic figure with the head of Bes in its profile is usually part of an adoration scene, examples of which can be found on the Brooklyn papyrus and the Metternich stela (Sauneron 1970). In the rare cases of a missing central head (strongly rooted in Egyptian iconography), a conglomeration of animal heads (without a dominating central head) occurs. This conglomeration symbolises the complex but developed nature of the solar deity. The difference between the variant with a central head surrounded by additional heads and the variant of many heads without a dominating head also seems to be important in terms of the interpretation of a depiction. With very few exceptions, the four-headed variant represents the whole deity with four heads of the same animal - the ram. The theory that the heads in both variants may have a common message should not, however, be completely rejected. At this stage, the only thing that is clear is that the solar deity was a highly complex and complicated being.

\section{Additional heads - the main feature of multi-headed deities}

The presence of additional heads is the element that distinguishes the polymorphic group and also the one that defines it best. The variant of one head surrounded by a number of additional animal heads is fairly unique and can only be seen in the depictions analysed here. The idea of polycephaly itself was not foreign to Egyptian religious thought. It was strongly rooted in the mixed form of traditional Egyptian iconography and clearly related to the concept of god. Here, it is worth mentioning 
the mysterious hybrid figure from the sarcophagus of Hawara from the 30th Dynasty of the Late period, which is found on the outside of the cover at head level (Hornung 2000, 16, fig. 13, footnote 61). This figure has a round core with a hieroglyphic text, two pairs of legs and two pairs of arms protruding in all directions, the heads of a ram, a goose and a snake and a fish tail. This figure is not analogous to anything else discovered in Egyptian iconography and has not yet been clearly interpreted.

A completely separate category of objects with additional heads is made up of statues in which additional heads are placed not around the central head, but on the figure's arms or tail. These heads perform a more complementary role and, alongside other elements of the mixed form, they enrich the depiction of the deity presented. Another interesting depiction can be found on one of the hypocephali of the Louvre (inv. no. N 3525A), which portrays a two-headed human figure with an additional eight schematic crocodile heads. However, as has already been pointed out, the polymorphic variant distinguishes itself not only by its visually distinct features, but also by the context of its occurrence and the functionality of the depiction. Its distinctive nature can be seen, for example, in pantheos images on magic gems. Other polycephalic figures most likely took the form of one of many variants depicting an individual deity.

Analysis of polymorphic iconography has demonstrated that it is most common for there to be a total of eight additional heads within this category. Unfortunately, the fact that other variants with different amounts of heads also exist has often been passed over in the subject's literature. As a result, the possibility of directly transferring the concept to the Nine-Shaped-One remains uncertain. In the polymorphic group, the lack of a figure with four additional heads is most surprising, bearing in mind that the number four is so often exploited in both Egyptian religion and magic. This area should therefore not be considered to merely represent a simple visualisation of previous emanations of the souls of god revealing themselves as the water $/ b a$ of Osiris, the earth/ba of Geb, the air/ba of Shu and the light $/ b a$ of Chepri (Koenig 2011, 247-251). J. F. Quack (2006a, 177) has investigated two possible interpretations of the additional animal heads seen in polymorphic depictions.

In the first, he assesses the thoughts of S. Sauneron (1960, 284-285), who proposed that the animal heads around Tutu's head depict so-called 'minor deities or demons', which number seven in total (Goyon 1985, 184-188; Dasen 2013, 67). The brief analysis of Tutu and other polymorphic 
depictions conducted by O. Kaper (2003, 97-99) allows us to immediately reject this hypothesis, since the number of heads usually numbers eight, although it may also be (for instance) six. The additional heads may not be the demons of Hormerti, the 'Lord of Messengers', but could perhaps be the deities and souls $(b a)$ of the holy site of Pharbaithos (Shedenu) in the eastern Delta (Gourlay 1979, 363-380). This explanation, which is more well-founded in Tutu's case, is too limited to have necessitated the development of polymorphic iconography and is also not reflected in sources from other areas.

The second interpretation proposes that the animal heads symbolised the transfer of animal powers to the deity (Quaegebeur 1985, 131-143), who would thus be able to take on specific, typical animal features in order to play a part in many areas of life. This hypothesis appears incredibly straightforward and is thus difficult to contradict or criticise. Polymorphic figures have unquestionably acquired animal features, but it is also clear that the theriomorphic elements contained within them are generally symbolic. It must be remembered that in Egyptian religion, an animal not only represented the presence, power and features of deities, but also the complex system of their emanating souls, which revealed itself in the entire shape of the animal.

S. Michel (2002, 11-12) has provided a completely different suggestion for pantheos figures. In her understanding, the additional heads symbolise the twelve shapes of the solar deity, which together form 'dodekaoros', the constellation of twelve hours that makes up the zodiac. However, the problem of the precise number of additional heads again appears, as a figure possessing twelve heads is only an occasional variant amongst polymorphic figures.

It would therefore seem that the number of additional heads should not guide our interpretation of their symbolism. However, it must be stated here that later magical ideas and associations pertaining to the Nine-ShapedOne (recorded on Greek papyri and other sources) are well-grounded and clearly do relate to the polymorphic figure's meaning. The freedom of the positioning of head location should also be mentioned. In twodimensional depictions, the heads can be located either around the central head or above it in the crown. Additionally, some depictions have clearly had their heads symbolically drafted in a manner that suggests that it is only their presence and uniform size that counts and not the species. We thus arrive at the next important point to be made in this analysis, namely that there 
appears to have been no unambiguous rules which governed the location of additional heads, the type of central head, the type of object upon which the depiction appeared or the species of animal used. The heads discovered thus far appear not to have been positioned according to an ordained pattern, although the possibility cannot be excluded that one may have existed that has not yet been identified.

However, it is possible to identify the species of animal which occurred most often. They could appear a maximum of twice in one representation, although such double variants are fairly rare. The eight most commonly identified animals are the falcon, the lion, the ram, the cat, the baboon, the crocodile, the bull and the dog/jackal, although it is difficult to 'rank' these animals according to the frequency of their occurrence. This is due to the poor condition of some of the figures, unclear head shapes, the often schematic nature of the depictions, the similarity of some of the species to each other (e.g. dog/jackal or cat/lion) and the fact that only slight differences exist between the quantities of certain animal types. Other animals which occur sporadically are the hippopotamus, the snake, the goose and the scarab.

The composition of the list of animals that occurred most frequently constitutes an important insight into Egyptian religion. It contains the species most important in the representation of the various deities and ideas and also provides an indication that the sets of additional heads should be treated as a collection that on the one hand is varied, but on the other is complete. Looking at the matter from this point of view, it can be assumed that the animals were always of identical size and without internal hierarchy or common repetition in order to symbolise the 'completeness' of the deity (Seyring 1935, 197-202). However, this 'completeness' (or the internal completion /closure of the deity's essence to encompass their many powers, features and characteristics) cannot be identified with pantheism. A comparison to universalism is more reasonable. Referring to the 'completeness' of the deity nevertheless seems to be the most convenient interpretation (Assmann 1979, 7-42; Assmann 2001, 230-244). This is shown by the presence of symbolic animal heads, which constituted a depiction of the $b a$ of the 'Hidden One'. The animals are earthly emanations of the $b a$ of the 'Hidden One', who reveals himself within the everyday world under the guise of creatures. The depiction of this deity as a universal being could have a great impact on the study of many related issues and could also be a reference point for the investigation of magical or healing practices. 
Even a very brief overview of the animals present in polymorphic iconography allows us to observe that it is dominated in particular by animals related to the solar circle (Malaise 1990, 680-729). The circle of Horus and his multiple 'warrior' forms can also be seen. Here, the solar aspect of the deity is undoubtedly connected to his universal aspect and emphasises the power and richness of his influence. The additional heads may thus be interpreted as a manifestation of the power of the god, his completeness, infinity, multiplicity and plenty (Koch 1993, 551-552). The solar influence is visible and as strong as the sun (Amun-Ra, Atum) in Egyptian religion. It expresses the full and complete nature of immensity and the concept of the unlimited. Another interesting observation can be made based mainly on the analysis of pantheos iconography on gems, as well as on some earlier amulets. Here, the schematic additional heads around the central head create something akin to beams and together resemble a halo composed of the sun's rays. This association may of course be the result of more recent associations with depictions of deities with halos from classical civilisations. However, it is worth noting that the schematic depiction of heads and their small size (in particular on the gems) may indicate more of a protective role and be a sign of their influence radiating out onto the external world in a similar manner to the classical halo (compare with the iconography of Helios: Fauth 1995).

\section{Conclusions}

The diversity of polymorphic representations poses a great challenge in the search for an unambiguous interpretation of their meaning. The most consistent interpretation is that polymorphic images are a means of depicting the solar and secret aspects of a particular deity. This is especially visible in the Late period and Graeco-Roman times, when there was a strong tendency towards the universalisation and simplification of religious messages. The attributes of particular deities used in constructing polymorphic representations were mainly those which played an essential role in the Cult of the Sun and their meaning would have been clear and coherent to people at the time (Vos 1999, 119-124; Quirke 2001, 25-27). A polymorphic representation may also be interpreted as a manifestation of divine presence in everyday life. Symbols of a deity's multiplicity, revealed in the $b a$ of the 'Hidden One', can also be observed in this type of image. The strong animal symbolism visible in these representations confirms the belief that divine care was afforded to humans in both a personal and official context. 
This personal care can be seen in the preventative magical functionality of certain representations, which is visible in the pantheos gems from the 2 nd and 3 rd centuries AD.

After comparing the possible interpretations of additional heads, the most important element in the construction of polymorphic iconography seems to be that it depicted the completeness, variety and multiplicity of the particular deity, including their numerous $b a$. In this way, a universal being was created that could have influence in an unending way. The animals symbolised the different powers of each of the $b a$ and emphasised both the solar and 'combative' nature of the figure. Considered from a visual standpoint, the additional heads also greatly contribute to the significance of the whole polymorphic figure, although the fact that other elements enrich this message should not be forgotten (Kaper 2003, 91-99).

\section{References}

Assmann J. 1979. Primat und Transzendenz. Struktur und Genese der ägyptischen Vorstellung eines 'Höchsten Wesens'. In W. Westendorff (ed.), Aspekte der spätägyptischen Religion, 7-42. Wiesbaden.

Assmann J. 2001. The Search for God in Ancient Egypt. London. [= Ägypten. Theologie und Frömmigkeit einer frühen Hochkultur, 1984].

Czerkwiński P. 2011. Can flames ensure immortality to humans? A few words on hypocephali and their significance for the dead in the culture of ancient Egypt. In J. Popielska-Grzybowska and J. Iwaszczuk (eds), $19-25$.

Dasen V. 2013. Dwarfs in Ancient Egypt and Greece. Oxford.

Derchain Ph. 1969. Le démiurge et la balance. In Religions en Égypte, hellénistique et romaine. Colloque de Strasbourg, 16-18 mai 1967, 31-34. (Bibliothèque des centres d'études supérieures spécialisés. Travaux du Centre d'études supérieures spécialisé d'histoire des religions de Strasbourg). Paris.

Fauth W. 1995. Helios Megistos: zur synkretistischen Theologie der Spätantike. (Religions in the Graeco-Roman World 125). Leiden, New York, Cologne. 
First G. 2011. Polymorphic or pantheistic deities? Some problems with identification and interpretation. Contribution to the manifestation of god in late Egyptian religion and magic. In J. PopielskaGrzybowska and J. Iwaszczuk (eds), 53-64.

Fischer H. 1987. The ancient Egyptian attitude towards the monstrous. In A. Farkas, P. Harper and E. Harrison (eds), Monsters and Demons in the Ancient and Medieval Worlds. Papers Presented in Honor of Edith Porada, 13-26. Mainz.

Gee J. 2001. Towards an interpretation of hypocephali. In H. Györy (ed.), 325-334.

Gourlay Y. J.-L. 1979. Les seigneurs et les baou vivants à Chedenou. In Hommages à la mèmoire de Serge Sauneron 1927-1976, 363-380. (BdE 81/1). Cairo.

Goyon J. C. 1985. Les dieux-gardiens et la genèse des temples (d'après les textes ègyptiens de l'èpoque grèco-romaine). Cairo.

Györy H. (ed.) 2001. Le lotus qui sort du terre: Mélanges offerts à Edith Varga. (Bulletin du Musée Hongrois des Beaux-Arts Supplément 2001). Budapest.

Hagen A. 2007. Gorgo: Apotropaism and Liminality. 1-65.

Haslauer E. 2001. Hypocephali in Wien und im Asasif. In H. Györy (ed.), 173-184.

Hornung E. 2000. Komposite Gottheiten in der ägyptischen Ikonographie. In Ch. Uehlinger (ed.), 1-20, 46-47.

Jelínková-Reymond E. 1956. Les inscriptions de la statue guérisseuse de Djed-Her-La-Sauveur. Cairo.

Junod E. 1982. Polymorphie du dieu sauveur. In J. Ries, Y. Janssens and J. M. Sevrin (eds), Gnosticisme et monde hellénistique. Actes du Colloque de Louvain-la-Neuve (11-14 mars 1980), 38-46. Louvain.

Kákosy L. 1966. Der Gott Bes in einer koptischen Legende. Acta Antiqua Academiae Scientiarum Hungaricae Budapest 14, 185-196.

Kákosy L. 1977. S.v. Mischgestalt. In L̈̈ 2, 145-148.

Kákosy L. 2000. Bemerkungen zur Ikonographie der magischen Heilstatuen. In Ch. Uehlinger (ed.), 45-49.

Kákosy L. 2002. A propos des statues guerisseuses et d'une statues de Bes au musee du Louvre. In Y. Koenig (ed.), La magie en Égypte. Actes du colloque organisé par le Musée du Louvre les 29 et 30 septembre 2000, Louvre, conférences et colloques, 273-284. Paris.

Kaper O. 2003. The Egyptian God Tutu. A Study of the Sphinx-God and Master of Demons with a Corpus of Monuments. (Orientalia Lovaniensia Analecta 119). Leuven. 
Koch K. 1993. Geschichte der ägyptischen Religion. Von den Pyramiden bis zu den Mysterien der Isis. Stuttgart, Berlin, Cologne.

Koenig Y. 1998. La polymorphie divine en Égypte. In W. Clarysse, A. Schoors and H. Willems (eds), Egyptian Religion: the Last Thousand Years. Studies Dedicated to the Memory of Jan Quaegebeur. Part 1: Archaeologica, Texts, Gods, 661-664. Leuven.

Koenig Y. 2011. Histoires sans paroles (P. Deir al-Medîna 45, 46, 47). BIFAO 111, 243-255.

Leitz Ch. 1994. Tagewählerei: das Buch h3t nhh ph.wy dt und verwandte Texte. ( $\ddot{A} A$ 55). Wiesbaden.

Lieven A. von 2005. (rev.) O. E. Kaper, The Egyptian God Tutu. (Orientalia Lovaniensia Analecta 119), Leuven 2003. OLZ 100, 30-33.

Malaise M. 1990. Bes et les croyances solaires. In S. Israelit-Groll (ed.), Studies in Egyptology Presented to Miriam Lichtheim, vol. 2, 680-729. Jerusalem.

Meeks D. 1986. Zoomorphie et image des dieux dans l'Égypte ancienne. In Ch. Malamoud and J.-P. Vernant (eds), Corps des dieux, 171-191. (Le temps de la réflexion 7). Paris.

Meeks D. 1991. Dieu masqué, dieu sans tête. Archéo-Nil 1, 5-15.

Miatello L. 2008. The hypocephalus of Takerheb in Firenze and the scheme of the solar cycle. SAK 37, 277-287.

Michaïlidis G. 1968. Bès aux divers aspects. BIÉ 45/Session 1963-1964, 53-93.

Michel S. 2002. Seele der Finsternis, Schutzgottheit und Schicksalsmacht: der Pantheos auf Magischen Gemmen. In W. Kemp, G. Mattenklott, M. Wagner and M. Warnke (eds), Vorträge aus dem Warburg Haus 6, $1-40$.

Myśliwiec K. 1978. Studien zum Gott Atum. Band 1: Die heiligen Tiere des Atum. (Hildesheimer Ägyptologische Beiträge 5). Hildesheim.

Naville E. 1894. Ahnas el Medineh (Heracleopolis Magna) with Chapters on Mendes, the Nome of Thoth, and Leontopolis. London.

Niwiński A. 1989. The Solar-Osirian unity as principle of the theology of the "State of Amun" in Thebes in the 21st Dynasty. Jaarbericht van het Vooraziatisch-Egyptisch Gezelschap Ex Oriente Lux 30 (1987-1988), 89-106.

Niwiński A. 2000. Iconography of the 21st dynasty: its main features, levels of attestation, the media and their diffusion. In Ch. Uehlinger (ed.), 21-43.

Ogden J. 1985-1986. Some notes on the Iconography of the God Min. Bulletin of the Egyptological Seminar 7, 29-41. 
Piankoff A. 1964. The Litany of Re, Egyptian Religious Texts and Representations. (Bollingen Series 40/4). Bollingen.

Pleyte W. 1881. Chapitres supplementaires du Livre des Morts 162 a 174, vol. 1. Leide.

Popielska-Grzybowska J. and Iwaszczuk J. (eds) 2011. Studies on Religion: Seeking Origins and Manifestations of Religion. (Acta Archaeologica Pultuskiensia 3). Pułtusk.

Quack J. F. 2006a. The so-called Pantheos. On Polymorphic Deities in Late-Egyptian Religion. In H. Györi (ed.), Aegyptus et Pannonia 3. Acta Symposii Anno 2004, 175-190. Budapest.

Quack J. F. 2006b. Ein neuer Zeuge für den Text zum Neunköpfigen Bes (P. Carlsberg 475). In K. Ryholt (ed.), The Carlsberg Papyri 7. Hieratic Texts from the Collection, 53-64. Copenhagen.

Quaegebeur J. 1985. Divinités égyptiennes sur des animaux dangereux. In L'animal, l'homme, le dieu dans le Proche-Orient ancien. Actes $\mathrm{du}$ Colloque de Cartigny, 1981, 131-143. (Les Cahiers du Centre d'Etude du Proche-Orient Ancien, Université de Genève 2). Leuven.

Quaegebeur J. 1991. Les quatre dieux Min. In Religion und Philosophie. Festgabe Derchain, 253-268.

Quirke S. 2001. The cult of Ra. Sun-Worship in Ancient Egypt. London.

Romano J. 1980. The origin of the Bes-image. Bulletin of the Egyptological Seminar 2, 39-56.

Sauneron S. 1960. Le nouveau sphinx composite du Brooklyn Museum et le role du dieu Toutou-Tithoes. JNES 19/4, 269-287.

Sauneron S. 1970. Le papyrus magique illustré de Brooklyn (Brooklyn Museum 47.218.156). Brooklyn.

Seyring H. 1935. Tithoës, Totoës et le sphinx panthèe. ASAE 35, 197-202.

Sternberg el-Hotabi H. 1987. Die Götterdarstellungen der Metternichstele. Ein Neuansatz zu ihrer Interpretation als Elemente eines Kontinuitätsmodells. GM 97, 25-68.

Sternberg el-Hotabi H. 1999. Untersuchungen zur Überlieferungsgeschichte der Horusstelen. Ein Beitrag zur Religionsgeschichte Ägyptens im 1. Jahrtausend v. Chr. Teil 1: Textband. Teil 2: Materialsammlung. ( $\ddot{A} A$ 62). Wiesbaden.

Stroumsa G. G. 1981. Polymorphie divine et transformations d'un mythologème: l'Apocryphon de Jean et ses sources. Vigiliae Christianae 35, 412-434.

Uehlinger Ch. (ed.) 2000. Images as Media: Sources for the Cultural History of the Near East and the Eastern Mediterranean. (Orbis Biblicus et Orientalis 175). Göttingen. 
Vallée B. 2009. Les hypocéphales: une glorification lumineuse d'Osiris. In A. A. Maravelia (ed.), En quête de la lumière/In Quest of Light: Mélanges in Honorem Ashraf A. Sadek, 137-144. Oxford.

Volokhine Y. 1994. Dieux, Masques et Hommes: À Propos de la formation de l'iconographie de Bès. Bulletin de la Société d'Egyptologie 18, 81-95.

Volokhine Y. 2000. La Frontalitè dans l'iconographie de l'Egypte Ancienne. (Cahiers de la Société d'Égyptologie 6). Geneve.

Vos R. L. 1999. S.v. Atum. In Dictionary of Deities and Demons in the Bible, 119-124.

Wainwright G. A. 1925. Antiquities from Middle Egypt and the Fayûm, ASAE 25, 145-147.

Yoyotte J. 1977. Contribution à l'histoire du chapitre 162 du Livre des Morts. RÉg 29, 194-202.

Zivie-Coche Ch. 2004. Book I. Pharaonic Egypt. In R. Dunand and Ch. Zivie-Coche (eds), Gods and Men in Egypt 3000 BCE to 395 CE, 5-192. London. [= Dieux et hommes en Egypte 3000 avant JC - 395 après JC, 2002].

Grzegorz First c/o Institute of Archaeology Jagiellonian University grzegorz.first@gmail.com 